\title{
Good Enough for Government Work? An Incomplete Contracts Approach to the Use of Nonprofits in U.S. Federal Procurement
}

\author{
${ }^{1}$ Economics, Samford University, 800 Lakeshore Dr., Birmingham, AL 35229, USA, E-mail: jpthornt@samford.edu. \\ https://orcid.org/0000-0001-9941-7524. \\ ${ }^{2}$ Watts College of Public Service and Community Solutions, Arizona State University, Tempe, AZ, USA, E-mail: jdlecy@asu.edu
}

\begin{abstract}
:
This paper examines the use of the nonprofit organizational form to mitigate the impact of incomplete contracts in the public sector Transaction costs economics (TCE) predicts that the expense of incomplete contracts will rise with contract complexity and asset specificity. Previous research shows that government agencies increase their use cost-plus style contracts to economize on these costs. However, cost-plus style contracts may also increase the propensity to inflate procurement costs, also known as gold-plating, when relationally specific investments are required. Consistent with this expectation, we find that federal agencies reduce their use of cost-plus style contracts as asset specificity rises. The paper then explores the use of nonprofit organizations as an alternative tool to reduce contracting costs. Using data from the Federal Procurement Data System, we examine the choice of organizational form by federal agencies, as contracts become more or less incomplete. Consistent with our hypotheses, we find that the use of nonprofit organizations increases with contract complexity. In contrast to cost-plus style contracts, we find that the use of nonprofits also increases with asset specificity. We apply this finding to support the conjecture that the nonprofit organization form is used by government agencies to mitigate contract incompleteness without the associated risk of cost inflation. We conclude by offering suggestions for why nonprofit contracts appear relatively infrequently in federal procurement data.
\end{abstract}

Keywords: nonprofit, FAADS, contracts, incomplete

DOI: $10.1515 / \mathrm{npf}-2019-0037$

\section{Introduction}

United States federal agencies are the largest purchasers of goods and services in the United States. In 2014, agencies issued over two million contracts with a total value of nearly four-hundred and fifty billion dollars. Federal agencies face a chain of complex decisions for each contract, which can be viewed broadly in three stages. First, the agency must determine whether it should make the product in-house, or contract with an external firm. Then, they decide what form or constrains to place into the contract. Finally, the agency chooses from whom to purchase those services.

Transaction Cost Economics (TCE) emerged in the late 1970s, primarily attributed to Oliver Williamson $(1979,1981)$, as a unifying theoretical framework for analyzing these decisions. Later, the theory was applied to help explain government procurement (Bajari, Houghton, and Tadelis 2014; Bajari and Tadelis 2001; Brown, Potoski, and Slyke 2016; Brown, Potoski, and Van Slyke 2010, 2015; Brown 2005). TCE predicts that the principle (in our case, government agencies) will economize on their transactions. This implies that agencies will make contracting decisions (i. e. make/buy, contract form, and the contracting firm) that minimize the overall cost of the transaction. TCE characterizes every transaction as governed by an implicit or explicit contract that attempts to describe the key elements of the transaction (e. g. price, timing, product characteristics). Contracts, however, are costly to construct. The TCE literature emphasizes two determinates of contracting cost, complexity, and asset specificity (Tadelis and Williamson 2012). Complexity refers to the effort and resources required to specify all the relevant contingencies in a contract. Predictably, these costs escalate as the task underlying the contract becomes more complicated. Asset specificity refers to relationally specific investments that are idiosyncratic to the contract. These may be physical assets, but can just as easily be human capital or information technology investments. The relevant trait is that those investments are valuable only within the context of a 
specific contract. To the extent that these investments are sunk, one party could demand ex-post adaptations to the contract (i. e. hold-up) that reduce the overall value of the transaction (Tadelis 2002).

This paper empirically examines the use of the nonprofit organizational form as a mechanism to reduce transaction costs. The idea that the nonprofit organizational form may reduce transaction costs was articulated as far back as Hansmann (1980), which identified the non-distribution constraint as a mechanism to reduce opportunistic behavior by the firm. Because nonprofit managers cannot consume the residual (revenues in excess of costs) as cash, the pecuniary incentive to shirk on non-contractible quality should be mitigated. ${ }^{1}$ Hansmann's paper connects the nonprofit organizational form to the TCE literature by identifying the non-distribution constraint as a contractually relevant feature.

Subsequently, a small, but expanding, literature had developed which examines government choice to contract with nonprofit organizations (Bennett and Iossa 2007; Bennett, Iossa, and Legrenzi 2003; Feiock and Jang 2009; Lamothe and Lamothe 2006; Witesman and Fernandez 2012). This literature now bridges a connection between the TCE nonprofit theory and government procurement literatures. We briefly sketch out some of the theoretical predictions of this literature below. Empirical evidence, however, is still emerging and has faced significant data limitations. We believe that ours is the first paper to specifically analyze the choice of government agencies to contract with nonprofit within a TCE framework.

Our paper will examine whether the nonprofit organizational form serves as a useful tool to lower transaction costs when government procurement contracts are incomplete. We find that, consistent with theoretical predictions, federal agencies use nonprofits more frequently when contracts are more complex. Moreover, federal agencies continue to increase their use of nonprofits when asset investments are more relationally specific. This is in contrast to cost-plus contracts, which are reduced with high asset specificity. The evidence supports our conjecture that nonprofit organizations are a useful enhancement to traditional (and more studied) tools of cost reduction, because they mitigate the incentive to gold-plate procurement contracts.

The paper begins by surveying the policy instruments available to government agencies as they attempt to mitigate contracting costs. We then examine the use of nonprofit organizations in government contracts. We introduce a novel dataset and identification strategy to predict the use of nonprofits in government procurement. We offer some thoughts on why we observe relatively little use of the nonprofit form in the existing data.

\section{Theory}

Transaction costs typically emerge from three domains: the cost of obtaining the necessary information to construct a contract, the time and effort necessary to negotiate the contract, and the ongoing costs of monitoring and enforcing the contract. The degree of difficulty in designing a contract has been shown to be a significant influence of contract design for government agencies (Boerner and Macher 2008; Levin and Tadelis 2010).

Transaction Cost Economics emphasizes two particular characteristics of the contract: contract complexity and asset specificity (Tadelis and Williamson 2012; Williamson 1979, 1981). First, contract complexity describes the relative difficulty of stipulating the precise quality or quantity of a contract output. Often, complexity is derived from uncertainty about the production process (such as invention of new technologies, vendor aptitude to perform a novel service, or environmental conditions that can impact project cost).

Complexity can also be driven by opportunities for strategic defection by one of the contracting parties. For this circumstance Brown, Potoski, and Van Slyke (2010) adopt the terminology of Hart and Moore (2008), which describes perfunctory versus consummate actions. An agent may apply the minimal effort required by the contract (perfunctory) or additional effort to the benefit of the principal (consummate). Importantly, these actions are difficult to prove to some governing authority (i. e. they are non-verifiable). Strategic defection can take a wide variety of forms, including shirking, opportunism, or excessive risk taking.

Second, contracting costs may be exacerbated by high levels of asset specificity. This occurs when either contracting party must make costly investments in the production process that are irrecoverable in the secondary market (a sunk cost). When this occurs, the counterparty can make demands (also known as ex-post adaptations), that may substantively increase overall costs of the contract (Bajari and Tadelis 2001; Bajari, Houghton, and Tadelis 2014). As an example, contractors often invest in software, facilities, or production technologies that are idiosyncratic to the government contract. They may also shoulder implicit costs, such as re-tasking personnel or rearranging organizational structures. A key distinction of these investments is that they are only valuable within the context of the particular contract. Consequently, either party could attempt to gain advantage by making excessive demands after production has begun. These two dimensions of the contract influence a sequential set of the decisions by the principal. For our summary, we organize them as the: make/buy decision, contract form decision, and the contractor decision. 


\subsection{Make vs Buy Decision}

TCE predicts that federal agencies will act to reduce contracting costs through a range of tools. Foremost, government agencies may choose whether to produce a good or service (the "make" decision), or to purchase the good or service from a third party (the "buy" decision) (Van Slyke 2007). Some contracts may draw on elements of both. In this decision, agencies face a tradeoff. The main advantage to an arm's-length transaction is that it engages high powered incentives for cost reduction. Vendors bear the full risk of cost overruns, as well as the potential gains from cost savings. In a competitive bidding environment, the government agency will extract the full benefit of low-cost production for itself.

However, purchasing the good or service via a market transaction requires writing a contract that fully specifies the relevant quality and quantity parameters. This may be trivial for services that are simple and observable, such as janitorial or landscaping services. However, constructing complete contracts can become prohibitively difficult as the complexity of the good or services rise, as may be the case with law enforcement, environmental clean-up, or cyber-security services. Just as important, there may be no easy mechanism to handle ex-post adaptations to the contract, where one party or the other wishes to materially change the terms of the contract. This can lead to costly renegotiations that may overwhelm the value of the original contract (Bajari, Houghton, and Tadelis 2014). A contract requiring significant investments in relationship specific assets exacerbates the problem. Because of large specific investments, it becomes prohibitively costly to switch vendors, increasing the possibility of hold-up.

In light of these problems, government agencies may prefer to keep production in-house (the "make" decision). Under this regime, transactions occur through a hierarchy, which deliberately mute high-powered incentives (Alchian and Demsetz 1972). Compared to market transactions, incentives toward productive efficiency will be reduced. However, administrative (versus market) control may be preferable, if ex-post contract adaptation becomes more likely or frequent (Tadelis and Williamson 2012).

A series of empirical papers have generated support for the hypothesis that local government agencies economize on transaction costs by "buying" services that are relatively simple to define and monitor, while "making" services that are relatively complex or require specific relational assets (Brown and Potoski 2005; Brown, Potoski, and Van Slyke 2006, 2010; Levin and Tadelis 2010). Federal contracts have also been studied and found to respond in similar ways to minimize contracting costs (Crocker and Reynolds 1993).

\subsection{Cost-Plus vs. Fixed Price Contracts}

Conditional on the government agencies deciding to contract out (or buy) a good or service, the agency may also vary the form of the procurement contract offered to the vendor. While there are numerous varieties of contract forms, most federal contracts may be categorized along a spectrum of fixed price vs. cost-plus (Kim and Brown 2012; Kim, Roberts, and Brown 2016; Tadelis and Bajari 2006). As the name implies, fixed price contracts prescribe a defined bundle of outputs at a predetermined price. In contrast, a cost-plus contract typically remunerates the vendor for the cost of production, plus some fee or percentage of the total cost as profit.

Fixed price contracts are typically preferred by the principal because the agent bears the risk for cost or scheduling overruns. ${ }^{2}$ The fixed price contract incents low cost production, because vendors can directly profit from lower cost technologies, dollar for dollar. In a competitive bidding environment, those lower costs should be passed along to the federal agency. However, fixed cost contracts may become prohibitively costly to negotiate as contract complexity increases. Perhaps even more important, production contracts relying on significant relationship specific investments may induce costly ex-post renegotiation, which can easily overwhelm the financial benefits of the initial contract (Bajari and Tadelis 2001).

In contrast, cost-plus contracts allow any unforeseen increases in cost to be passed along to the purchaser. Thus, they are flexible to deviation in contract requirements, and reduce the potential for renegotiations. Furthermore, they are relatively simple to construct, since price flexibility is built into the contract. By design, the risk of cost overruns is borne by the government agency. Previous empirical research has demonstrated that low-complexity contracts will more often be structured as fixed-price, while higher complexity contracts are more likely to be structured as cost-plus (Kim and Brown 2012; Kim, Roberts, and Brown 2016; Tadelis and Bajari 2006).

Perversely, to the extent that profits for the vendors are a function of costs, there exists an embedded incentive to escalate those costs once the contract is executed (Iossa and Martimort 2016). This incentive is exacerbated when asset specificity is high, because it is - by definition - costly for the government agency to renegotiate the contract or change vendors. The inflation of costs when relationship assets are high has been described, in practice, as "gold-plating" (Brown, Potoski, and Slyke 2016; Kim and Brown 2012; Kim, Roberts, and Brown 2016). The propensity for gold-plating a contract will rise with asset specificity, within the context of a cost- 
plus contract (Brown, Potoski, and Slyke 2016). Consequently, we predict that the use of cost-plus contracts will decline as asset specificity rises in order to reduce the potential for ex-post cost inflation.

\subsection{Organizational Form: Nonprofit and For-profit Contractors}

Finally, and novel to this paper, a government agency may choose to contract with either a for-profit or a nonprofit firm. The non-distribution constraint (where the nonprofit has no residual claimant) softens the incentive for opportunistic behavior (e. g. non-contractible quality or ex-post renegotiation) simply because there is less to be gained by doing so (Young et al. 2010; Young and Casey 2006). In this way, diluted incentives for self-dealing may improve cooperation and result in more stable systems of mutually beneficial relationships (Valentinov 2014; Valentinov and Chatalova 2016).

Interestingly, Hansmann $(1980,888)$ specifically notes that the nonprofit organizational form should have the same impact as a cost-plus contract, because it places as similar (if more extreme) limitation on the firm. While not offering a formal model, Hansmann outlines his basic intuition. Where a cost-plus contract requires a dedicated fraction of the contract revenue to be allocated to production, the non-distribution constraint implicitly forced the firm to allocate all of the contract revenue to production. More formally, the nonprofit organizational form can be viewed as the extreme (i. e. complete) case of the separation of ownership from control, as modeled in Jensen and Meckling (1976). The nonprofit literature has tended to focus on the positive aspects of this ownership structure, where the manager incentives to lower non-contractible quality or engage in gold-plating are muted. The finance literature has tended to focus on the negative aspects of this ownership structure. When managers are separated from ownership, they bear a lower cost for any perquisite consumption and bear less risk for uncertain ventures (Fama and Jensen 1983; Jensen 2016).

We make the conjecture that principals will choose to contract with for-profit firms for relatively simple contracts in competitive markets. Because of the built-in profit maximization incentive, the owner of a forprofit firm has a high-powered incentive to provide the good or service at the lowest possible cost. In the case of a competitive bidding market, these cost savings will be passed along to the government agency (Carril and Duggan 2018).

We also make the conjecture that the nonprofit organizational form will be useful as contracts become more complex. In this way we expect (as did Hansmann) that the use of the nonprofit organizational form will behave similarly to cost-plus contract. Both the use of the cost-plus contract and the nonprofit organizational form should rise with contract complexity.

Our predictions become more interesting when investments are relationship specific (or idiosyncratic) to the procurement contract. As discussed previously, this is a weakness for the cost-plus contract, because it generates lock-in to a particular firm. This gives that firm the opportunity to "gold-plate" a contract by padding its costs. We expect that the nonprofit organizational form will mitigate against this effect for two reasons. First, the nonprofit organizational form offers a credible signal of goal alignment between the principal and the agent (Bennett and Iossa 2009; Besley and Ghatak 2001; Brown and Troutt 2004; Valentinov 2007; Van Slyke 2007). Relative to for-profit firms, it is more likely that nonprofit firms will have objectives in line to the contracting agency and be considered more trustworthy, thereby reducing monitoring and enforcement costs associated with opportunism (Bryce 2012; Fernandez 2009; Prüfer 2011; Witesman and Fernandez 2012).

Second, the nonprofit organizational form maintains a public and legal prohibition against private inurement (i. e. the non-distribution constraint) where there is no legal residual claimant (Hopkins 2011). Because managers cannot directly consume marginal profits as cash, the incentive to undertake such reductions in quality will be reduced, relative to for-profit firms (Ferris and Graddy 1991; Glaeser and Shleifer 2001).

For these reasons, we expect that the use of the nonprofit organizational form will be preferred to the costplus contract under conditions where both complexity and asset specificity exist. To the extent that nonprofit firms are less likely to engage in opportunistic behaviors, or demonstrate better goal alignment, contracting costs should be lower for nonprofit relative to their for-profit counterparts. This paper examines this question empirically by looking to see if government agencies attempt to lower transaction costs by using nonprofits more as contracts become both more complex and asset specific.

We conduct our analysis in two stages. First, we validate our data and identification strategy by first replicating the findings of Brown and Potoski (2005) and Levin and Tadelis (2010) with our own sample data. These papers demonstrate that private sector contractors increase their usage of cost-plus contracts when complexity increases, as TCE predicts. We confirm this finding with federal agencies, indicating that our treatment variables and empirical strategy are consistent with the previous TCE papers.

Second, we test for the impact of contract complexity on the use of nonprofit organizational form in federal contracts. For the reasons described above, we expect that the use of nonprofits by federal agencies will increase with contracts that are more complex. Furthermore, unlike CP contracts, nonprofit organizations do not suffer the same incentive for gold-plating. Thus, their use should also increase with asset specificity. 


\section{Data}

Our study uses the Federal Procurement Data System - Next Generation (FPDS-NG), which catalogs all federal agency contracts greater than three thousand dollars, as well as all modifications to those contracts. The FPDSNG reports contract data via a web portal, www.usaspending.gov, which is updated nightly. The dataset is large, containing over 1.5 million contracts in 2014.

For tractability, we have constrained our sample in several ways. First, we examine only contracts - as opposed to grant awards - which are analyzed in a separate paper. Second, we isolate contracts that are newly issued in 2014, excluding contract renewals and adjustments. Third, we isolate our analysis to five agencies: The Departments of: Agriculture, Justice, Homeland Security, Health \& Human Services, and the General Services Administration. These five agencies represent the largest non-defense related agencies, by number of contracts in 2014. These adjustments reduce the total number of contract observations to 390,521. Finally, our sample is reduced to those federal contracts which are described in Levin and Tadelis (2010) and Brown and Potoski (2005). These two papers are used to generate our treatment variable, described in the next section. Our final sample is 38,855 federal contracts in 2014. This selection process is discussed in detail in Section 4.2.

\subsection{Dependent Variables}

The paper uses two dependent variables. The first dependent variable characterizes whether federal contracts are formed as a cost-plus $(\mathrm{CP}=1)$ or fixed price $(\mathrm{CP}=0) .^{3}$ Table 1 summarizes the distribution of contract form by U.S. federal agency. Consistent with federal policy, relatively few $(15.3 \%)$ of contracts in the FPDS-NG database are formed as cost-plus. Health and Human Services is a disproportionate user of cost-plus contracts in the sample, using both the highest number $(3,454)$ and the greatest percentage $(59 \%)$ of its contracts as cost-plus in the sample.

Table 1: Full sample tablulation by contract type.

\begin{tabular}{lllll}
\hline & Cost-Plus & \multicolumn{3}{l}{ Fixed Price } \\
\hline Department of Agriculture & 265 & $2.6 \%$ & 9,951 & $97.4 \%$ \\
Department of Justice & 2,156 & $15.8 \%$ & 11,495 & $84.2 \%$ \\
Department of Veterans Affairs & 4 & $0.1 \%$ & 6,989 & $99.9 \%$ \\
General Services Administration & 33 & $1.8 \%$ & 1,839 & $98.2 \%$ \\
Health \& Human Services & 3,454 & $59.0 \%$ & 2,402 & $41.0 \%$ \\
& 5,912 & $15.3 \%$ & 32,676 & $84.7 \%$ \\
& & & & \\
\hline & Nonprofit & & For Profit & \\
\hline Department of Agriculture & 90 & & & \\
Department of Justice & 2,627 & $0.9 \%$ & 10,126 & $99.1 \%$ \\
Department of Veterans Affairs & 917 & $19.2 \%$ & 11,024 & $86.8 \%$ \\
General Services Administration & 77 & $13.1 \%$ & 6,076 & $95.9 \%$ \\
Health \& Human Services & 109 & $4.1 \%$ & 1,795 & $98.1 \%$ \\
& 3,820 & $1.9 \%$ & 5,747 & $90.1 \%$ \\
\hline
\end{tabular}

Our primary interest in this paper is to predict the use of nonprofit organizations by federal agencies (NONPROFIT =1). Table 1 also partitions the sample by agency and organizational form. Again, the unit of observation is the contract. For example, the Department of Agriculture issued 10,216 contracts in the sample. Of these, 10,126 (99.1\%) were issued to for-profit organizations. Of the five agencies analyzed, the Department of Justice is the most prolific user of nonprofits (19.2\%), the Department of Agriculture is the least frequent user (0.9\%).

Table 2 presents a simple cross-tabulation of cost-plus and nonprofit contracts in the sample. Seventy five percent of the sample contracts $(28,870)$ are awarded to for-profit firms as fixed-price contracts. Fifteen percent of sample contracts are awarded to for-profits as cost-plus contracts. Ten percent of the sample is awarded to nonprofits as fixed-price contracts. Only a trivial number $(n=14)$ of the contracts in the sample are both cost-plus and awarded to nonprofits. That federal agencies use either cost-plus style contract or nonprofit organizations - but almost never both - is useful for our analysis. In our next section we explore the conditions under which federal agencies may choose nonprofit organizations as a substitute for cost-plus style contracts. 
Table 2: Full sample tablulation by contract type.

\begin{tabular}{lllll}
\hline & & \multicolumn{2}{l}{ Nonprofit } & \\
\cline { 3 - 5 } & & No & Yes & Total \\
\hline Cost Plus & No & 28,870 & 3,806 & 32,676 \\
Contract & Yes & 5,898 & 14 & 5,912 \\
& Total & 34,768 & 3,820 & 38,588 \\
\hline
\end{tabular}

\subsection{Explanatory Variables Measuring Contractibility and Asset Specificity}

Our treatment variables are measures of complexity and asset specificity for the procurement contract. We apply two schemes, developed independently, in Brown and Potoski (2005) and Levin and Tadelis (2010) to generate our treatment. Both papers survey local purchasing managers regarding the relative complexity of contracting and asset specificity for various services. ${ }^{4}$

Brown and Potoski (2005) survey 75 purchasing managers over 64 common contracts regarding their relative complexity. ${ }^{5}$ The purchasing managers scored each contract over a range of measurement and asset specificity. We extract this information for non-contractibility and asset specificity from their study using the NAICS codes, and then match those codes directly to federal contracts. The sub-sample generated using the Brown and Potoski (2005) method yields 23,122 observed contracts from the FPDS-NG. ${ }^{6}$

A similar approach was used for Levin and Tadelis (2010). They surveyed 23 city managers over 29 distinct services. Two of their survey items are comparable to the BP survey, these items ask for information about the ease of measurement (complexity), and the potential for holdup (asset specificity). Again, we extract the relevant NAICS codes from the study and code the respective contracts from the FPDS-NG. The sub-sample generated using the LT scheme includes twenty-four NAICS codes and yields 15,476 unique contracts. ${ }^{7}$

The survey instruments from each paper use distinct ordinal scales. To accommodate this measurement issue, we convert both of their ordinal scales into binomials using the authors' own criteria to categorize responses as either Complex/Not Complex and Asset Specific/Not Asset Specific. ${ }^{8}$ Our Table 3 offers a visual summary of the two survey schemes by depicting each NAICS code in the sample, organized by whether it was classified as complex or asset specific. There are sixty-three unique NAICS contract codes represented in both samples. The non-italicized code numbers represent the BP categorization, while the italicized codes represent LT surveys.

Table 3: Tablulation of NAICS codes.

\begin{tabular}{|c|c|c|c|c|c|c|c|}
\hline \multirow{3}{*}{ Asset Specific } & \multirow[b]{3}{*}{ No } & \multicolumn{6}{|c|}{ Complex } \\
\hline & & \multicolumn{3}{|l|}{ No } & \multicolumn{3}{|l|}{ Yes } \\
\hline & & 237,310 & 237,310 & 238,210 & 561,710 & 541,350 & \\
\hline & & 561,440 & 561,440 & 485,113 & 812,910 & 812,910 & \\
\hline & & 561,612 & 561,612 & 488,410 & & 541,820 & \\
\hline & & 561,730 & 561,730 & 488,490 & & 561,410 & \\
\hline & & 561,790 & 561,790 & 522,320 & & 541,612 & \\
\hline & & 561,990 & 561,990 & 532,112 & & 921,130 & \\
\hline & & 562,111 & 562,111 & 541,214 & & 926,110 & \\
\hline & & 562,212 & 562,212 & 541,620 & & 926,140 & \\
\hline & & 812,930 & 812,930 & 812,220 & & & \\
\hline & & 115,112 & 924,120 & 561,710 & & & \\
\hline & Yes & 221,310 & 221,310 & & 221,320 & 221,210 & 221,210 \\
\hline & & 562,213 & 221,320 & & 519,120 & 713,940 & 488,119 \\
\hline & & & 237,110 & & 712,110 & 712,110 & 621,910 \\
\hline & & & 485,111 & & 541,110 & 541,110 & 622,110 \\
\hline & & & 518,210 & & 541,350 & 622,210 & 561,591 \\
\hline & & & 519,120 & & 562,998 & 623,110 & 922,140 \\
\hline & & & 541,370 & & 621,420 & 623,220 & 922,160 \\
\hline & & & 562,211 & & 621,493 & 624,110 & 923,120 \\
\hline & & & 926,130 & & 624,120 & 624,221 & 237,130 \\
\hline & & & & & 624,410 & 624,410 & \\
\hline
\end{tabular}


Notes: NAICS numbers in black are from Brown and Potoski (2005)

NAICS numbers in italics are from Levin and Tadelis (2010)

Grey shaded cells indicate an overlap BP and LT for Complexity and Asset Specificity

Cross Hatched cells indicate a discrepency between BP and LT for either Complexity or

Asset Specificity

Non-shaded cells indicate the NAICS codes do not overlap Between Studies

There is some overlap in the contracted services across the two sub-samples. The greyed cells represent where BP and LT both include a particular NAICS contract, and classify that contract the same way (complex or asset specific). For example, in the top left corner, both BP and LT include NAICS code 237310 (Electricity Utility operation and management), and classify that contract as complex and asset specific. Twelve of the NAICS codes are categorized consistently in both LT and BP samples. However, four of the NAICS codes are categorized inconsistently. For example, NAICS code 56710 (Insect/rodent control) is classified by BP as Not Asset Specific and Complex, but is categorized by LT as Not Asset Specific and Not Complex. These are noted by the crossedhatched cells. ${ }^{9}$ Thirty-eight of the NAICS codes do not overlap between BP and LT surveys. Table 4 reports correlation coefficients between indicators for specific and complex for both sample sets. The two sub-samples (BP \& LT) have a correlation of roughly 0.6.

Table 4: Correltation coefficients of contractibility over sample set.

\begin{tabular}{lllll}
\hline & specific_BP & complex_BP & complex_LT & specific_LT \\
\hline specific_BP & 1.00 & & & \\
complex_BP & 0.76 & 1.00 & & \\
complex_LT & 0.36 & 0.60 & 1.00 & 1.00 \\
specific_LT & 0.61 & 0.53 & 0.81 & \\
\hline
\end{tabular}

Notes:

_BP indicates those observations drawn from Brown and Potoski (2005)

_LT indicates those observations drawn from Levin and Tadelis (2010)

For our empirical tests, we stack these two sub-samples to create a variable indicating the contract is complex $($ COMPLEX $=1$ ) or asset-specific (ASSET_SPECIFIC $=1$ ). Table 5 reports basic summary statistics for the dependent variables. The sample is roughly symmetric in the treatments, with $57 \%$ of the sample as COMPLEX $=1$ and $65 \%$ of the sample as SPECIFIC $=1$.

Table 5: Summary of variables.

\begin{tabular}{|c|c|c|c|c|c|c|}
\hline Dependent Variables & Abbreviation & $\mathrm{n}$ & mean & s.d. & $\min$ & $\max$ \\
\hline Nonprofit & $\mathrm{NP}$ & 38,588 & 0.10 & 0.30 & 0.00 & 1.00 \\
\hline Cost Plus Contract & $\mathrm{CP}$ & 38,588 & 0.15 & 0.36 & 0.00 & 1.00 \\
\hline \multicolumn{7}{|l|}{ Treatment } \\
\hline Complex & COMPLEX & 38,588 & 0.57 & 0.49 & 0.00 & 1.00 \\
\hline Specific & SPECIFIC & 38,588 & 0.65 & 0.48 & 0.00 & 1.00 \\
\hline \multicolumn{7}{|l|}{ Covariates } \\
\hline Contract Value (000's) & $\begin{array}{l}\text { CONTRACT } \\
\text { VALUE }\end{array}$ & 38,588 & $\$ 271$ & $\$ 5,259$ & $\$ 0$ & $\$ 560,014$ \\
\hline Contractor Revenue (000's) & $\begin{array}{l}\text { CONTRACTOR } \\
\text { REVENUE }\end{array}$ & 38,588 & $\$ 1,789,848$ & $\$ 131,000,000$ & $\$ 0$ & $\$ 25,600,000,00$ \\
\hline \# of Bids & BIDS & 38,457 & 2.00 & 2.19 & 0.00 & 10.00 \\
\hline Duration in Years & DURATION & 35,325 & 1.07 & 1.76 & 0.00 & 91.06 \\
\hline $\begin{array}{l}\text { Brown \& Potoski } \\
\text { Treatment }\end{array}$ & $\mathrm{BP}$ & 38,588 & 0.60 & 0.49 & 0.00 & 1.00 \\
\hline
\end{tabular}

\subsection{Covariates}

Table 5 offers summary statistics for each of the remaining covariates. We include a vector of contract characteristics to control for heterogeneity in the contracting environment. CONTRACT VALUE is the dollar value of 
the contract, in thousands. CONTRACTOR REVENUE is the total revenues of the contract recipient, in thousands of dollars. Number of BIDS proxies for the competitiveness of the bidding process by offering the total number of bids for that particular contract. DURATION is the total duration of the contract, measured in years. Each of these previous variables are distributed non-normally, thus we take their natural logarithms before the regression analysis.

Finally, we include an indicator, BP which equals unity if is drawn from Brown and Potoski (2005), otherwise the treatment is drawn from Levin and Tadelis (2010). This will allow us to segment the regression by treatment to test the model robustness.

Model (1) is as follows:

$C P$ equals unity if the contract $i$ issued by agency $j$ in states is awarded as a cost-plus style contract; zero indicates the contract was fixed price.

$$
\begin{aligned}
\left\{C P_{i j s}\right\} & =\alpha+\beta C O M P L E X_{i}+\gamma \text { ASSET_SPECIFIC } i+\sum_{j} \delta A G E N C Y_{j} \\
& +\sum_{s} \text { BSTATE } E_{s}+\sum_{s} \varphi C O N T R A C T C O V A R I A T E S_{i}+\mu B P_{i}+\varepsilon_{i j s}
\end{aligned}
$$

Model (2) is as follows:

NONPROFIT equals unity if the contract $i$ issued by agency $j$ in state $s$ is awarded to a nonprofit organization; zero indicates the contract was awarded to a for-profit.

$$
\begin{aligned}
&\text { NONPROFIT } \left._{i j s}\right\}=\alpha+\beta \text { COMPLEX } \\
&+\gamma \text { ASSET_SPECIFIC } \\
&++\sum_{s} \text { BSTATE }_{s}+\sum_{s} \varphi \text { AGENCYNT } \\
&
\end{aligned}
$$

Our treatment variables are COMPLEX and SPECIFIC. COMPLEX is a binomial equal to unity if the NAICS contract code associated with the contract was identified as complex. SPECIFIC is a binomial equal to unity if the NAICS code was identified as requiring specific investments. We also include a vector of indicator variables for the federal AGENCY issuing the contact, and the STATE where the contract is executed. We include a vector of contract specific covariates described in Table 5. Finally, BP equals unity if contract I was drawn from the Brown and Potoski (2005) sample, zero if it was drawn from Levin and Tadelis (2010). This binomial will allow us to test if there are differences in the sub-samples.

Contract complexity data gathered from both Brown and Potoski (2005) and Levin and Tadelis (2010) provide distinct, independent, and validated data sources for contract complexity and asset specificity. Combining these two separate surveys increases the reliability of our study. Finally, we believe that we are the first study to apply this style of research design to federal contract data.

\section{Results}

The models are estimated using Logit. The results are summarized in Table 6, columns 1 and 2. In each case, the STATE control variables as well as CONTRACT covariates are suppressed for presentation purposes. Full regression results are reported in the Appendices C \& D.

Table 6: Logit regression results.

\begin{tabular}{lllll}
\hline Dependent Var & $\mathbf{1}$ & \multicolumn{2}{l}{$\mathbf{2}$} & \\
& $\mathbf{C P}$ & & $\mathbf{N P}$ & \\
\hline COMPLEX & 1.834 & $* *$ & 2.112 & $* *$ \\
s.e. & 0.109 & & 0.094 & \\
SPECIFIC & -1.529 & $* *$ & 0.962 & $* *$ \\
s.e. & 0.111 & & 0.105 & \\
BP & -0.187 & $* *$ & 0.778 & $* *$ \\
s.e. & 0.061 & & 0.071 & \\
Department of Justice & 4.913 & $* *$ & 2.089 & $* *$ \\
s.e. & 0.142 & & 0.132 & \\
Veterans Affairs & -2.729 & $* *$ & 1.923 & $* *$ \\
s.e. & 0.573 & & 0.139 & \\
General Service Adminstration & -0.048 & & 2.375 & $* *$
\end{tabular}




\begin{tabular}{lllll} 
s.e. & 0.139 & & 0.188 & \\
Health and Human Services & 4.593 & $* *$ & 0.946 & $*$ \\
s.e. & 0.106 & & 0.183 & \\
_cons & -10.384 & $* *$ & -7.469 & $* *$ \\
s.e. & 0.501 & & 0.375 & \\
& & & & \\
n & 35,243 & & 35,184 & \\
Psuedo R2 & 0.5162 & & 0.3982 & \\
\hline
\end{tabular}

Notes:

$\mathrm{BP}=1$ indicates that the sample overvation came from Brown and Potoski (2005)

$\mathrm{BP}=0$ indicates the sample observation came from Levin and Tadelis (2010)

Department of Agriculture is the base case for agency indicators

** indicates statistical significance at 0.01

\subsection{Cost-Plus Dependent Variable}

We first estimate the model using the cost-plus (CP) dependent variable. We run this initial regression to validate our data against the previous literature. Initial results are listed in column 1 of Table 6 . The probability of observing a cost-plus contract increases with contract complexity (COMPLEX $=1$ ). This finding is consistent with the literature described in Section 2.1. Thus, we are more confident that both our measures of complexity are valid and consistent with the previous empirical literature.

We also find that the use of cost-plus contracts is lower when assets are specific (SPECIFIC $=1$ ). Federal agencies appear to reduce their reliance on cost-plus style contract as those contracts require increasingly relationship specific investments. This finding is consistent with our conjecture that asset specific may induce gold-plating (described in Section 2.2). Thus, government agencies appear to respond to this incentive by reducing the use of $\mathrm{CP}$ contracts when assets are relationally specific.

Logit coefficients are cumbersome to interpret directly. Thus, it is helpful to look at marginal effects $\left(\frac{\delta y}{\delta x}\right)$ and for the main explanatory variables. These are summarized in Table 7. For the full sample, the probability of observing a cost-plus (CP) contract increases by eight percentage points when the contract is identified as complex. To check the robustness of our treatment, we split our results by the unbundled treatment sub-samples. Recall that BP $=1$ indicates our results for only the Brown and Potoski (2005) treatment. When only this piece of the treatment is activated, the probability of observing a CP contract increases by eight percentage points when the contract is complex. BP $=0$ indicates the treatment only for the Levin and Tadelis (2010) sub-sample. The effect is nearly identical for both sub-samples, and all results are statistically significant at normal confidence intervals.

Table 7: Predictive margins for CP.

\begin{tabular}{|c|c|c|c|c|c|c|c|c|}
\hline \multirow{2}{*}{\multicolumn{2}{|c|}{ Cost Plus }} & & \multirow[t]{2}{*}{$\mathrm{dy} / \mathrm{dx}$} & \multirow[t]{2}{*}{ Std. } & \multirow[t]{2}{*}{$\mathrm{z}$} & \multirow[t]{2}{*}{$P>z$} & \multicolumn{2}{|c|}{ [95 \% Conf. Interval] } \\
\hline & & & & & & & & \\
\hline & Full Sample & & 0.08 & 0.01 & 14.92 & 0.00 & 0.070 & 0.091 \\
\hline & & $\mathrm{BP}=1$ & 0.08 & 0.01 & 14.90 & 0.00 & 0.069 & 0.090 \\
\hline & & $\mathrm{BP}=2$ & 0.08 & 0.01 & 15.07 & 0.00 & 0.070 & 0.091 \\
\hline & SPECIFIC & & & & & & & \\
\hline & Full Sample & & -0.06 & 0.00 & -13.38 & 0.00 & -0.068 & -0.051 \\
\hline & & $\mathrm{BP}=1$ & -0.06 & 0.00 & -13.43 & 0.00 & -0.068 & -0.050 \\
\hline & & $\mathrm{BP}=2$ & -0.06 & 0.00 & -13.02 & 0.00 & -0.071 & -0.052 \\
\hline
\end{tabular}

$\mathrm{BP}=1$ indicates that only the Brown and Potoski (2005) treatment is applied.

$\mathrm{BP}=2$ indicates that only the Levin and Tadelis (2010) treatment is applied.

The impact of SPECIFIC (asset specificity) is also consistent with our expectations. Table 7 reports that, for the entire sample, we observe that asset specificity $($ SPECIFIC $=1$ ) results in a six percentage point reduction in costplus contracts for the entire sample. The results are nearly identical when we split the treatment into BP and LT subsamples. All results are statistically significant. From these results, we can be relatively confident that our treatment is consistent across both BP and LT sub-samples and that their application is suitable for federal contracts. 


\subsection{Nonprofit Dependent Variable}

Our primary interest for this paper lies in the impact of contract complexity and asset specificity on the use of nonprofits in federal procurement. These results are presented in Table 6, column 2.

Confirming our overall hypotheses from Section 2.3, the nonprofit organizational form serves a similar function as the cost-plus contract. We observe that, as contract complexity increases, the utilization of nonprofits organizational form rises. Unlike our results for $\mathrm{CP}$ contract, we also find that the use of nonprofit increases with asset-specificity (SPECIFIC). These results are statistically significant at normal confidence intervals. Consistent with our conjectures outlined in Section 2.3, we hypothesized that - because of goal alignment and the non-redistribution constraint - the nonprofit organizational form may serve as a useful contracting tool, particularly when assets are specific. Stated plainly, the nonprofit organizational form may, simultaneously, reduce the risk of gold-plating via moral hazard.

For clarity, we again present the marginal effects of the main treatment variables in Table 8. For the full sample, the probability of observing a contract with a nonprofit organization increases by eleven percentage points when that contract is considered complex. The results are consistent when separating the two treatment subsamples. The change in a contract to COMLEX $=1$ results in an increase in the probability of using a nonprofit by $7 \%$ for BP and $12 \%$ for LT sub-samples. All results are statistically significant. These findings confirm our hypotheses that federal agencies use nonprofit organizations more as contracts become increasingly complex. In this way, federal agencies are using nonprofits similarly to cost-plus contracts.

Table 8: Predictive margins for Nonprofit.

\begin{tabular}{|c|c|c|c|c|c|c|c|}
\hline NONPROFIT & & $\mathrm{dy} / \mathrm{dx}$ & Std. & $\mathbf{z}$ & $\mathbf{P}>\mathbf{z}$ & \multicolumn{2}{|c|}{ [95 \% Conf. Interval] } \\
\hline \multicolumn{8}{|l|}{ COMPLEX } \\
\hline \multirow{2}{*}{\multicolumn{8}{|c|}{$\begin{array}{l}\text { Full } \\
\text { Sample }\end{array}$}} \\
\hline & & & & & & & \\
\hline & $\mathrm{BP}=1$ & 0.07 & 0.0039 & 18.88 & 0.00 & 0.066 & 0.081 \\
\hline & $\mathrm{BP}=2$ & 0.12 & 0.0046 & 25.72 & 0.00 & 0.108 & 0.126 \\
\hline \multicolumn{8}{|c|}{ SPECIFIC } \\
\hline \multirow{3}{*}{$\begin{array}{l}\text { Full } \\
\text { Sample }\end{array}$} & & 0.05 & 0.0048 & 10.28 & 0.00 & 0.040 & 0.059 \\
\hline & $\mathrm{BP}=1$ & 0.05 & 0.0054 & 10.24 & 0.00 & 0.044 & 0.065 \\
\hline & $\mathrm{BP}=2$ & 0.04 & 0.0035 & 10.6 & 0.00 & 0.030 & 0.044 \\
\hline
\end{tabular}

$\mathrm{CP}=1$ indicates that only contracts that are catagorized as Cost Plus are analyzed.
$\mathrm{CP}=2$ indicates that only contracts that are catagorized as Fixed Price are analyzed.

However, we observe a divergence from $\mathrm{CP}$ behavior when looking at asset specificity (SPECIFIC). For the case of nonprofits (Table 6 column 2), federal agencies increase their usage of nonprofit when those contracts have a high degree of asset specificity. The marginal effects in Table 8 indicate that when a contract becomes relationally asset specific (SPECIFIC $=1$ ) the probability of observing a contract with a nonprofit increases by $5 \%$ for the entire sample, $5 \%$ for the BP sub-sample, and $4 \%$ for the LT sub-sample. All results are statistically significant at normal confidence intervals.

To restate our full results, we observe that contract complexity (COMPLEX) is associated with an increase in the probability of observing a cost-plus contract by federal agencies. Because this result is consistent with other research. Thus, we are more confident in our application of the treatment. The use of nonprofits also increases with contract complexity. This is consistent with our hypothesis that the nonprofit organizational form lowers contracting costs.

We also observe that asset specificity (SPECIFIC) is associated with a decrease in the use of cost-plus contracts. This is consistent with the literature on the potential for gold-plating contracts when assets are specific, though other stories could apply. In contrast, we observe that the use of nonprofits increases with asset specificity. This behavior diverges from the cost-plus contract. We discuss possible explanations for this in the next section.

The regressions were tested over a variety of specifications for robustness. Most importantly, our primary results are not sensitive to either the size of the contract, or to the sample of federal agencies used. ${ }^{10}$ We acknowledge and suspect that there exists important differences in how various federal agencies treat the nonprofit organizational form in their procurement process, however a clear pattern does not emerge in our data. A more fine-grain qualitative analysis of these practices would be a fruitful avenue of future research. 


\section{Discussion and Conclusions}

The aim of this paper has been to examine whether federal agencies adjust their use of nonprofit organizational form in response to changes in contracting costs. We start with the stylized fact that nonprofits represent only a small fraction of government contracts. We directly test the long-standing hypothesis that nonprofits may be used as a tool to mitigate agency problems in government contracts, via theories of goal alignment and the non-distribution constraint.

Using two independent schema for contract characteristics, we test the use of nonprofit organizations by federal agencies under differing levels of contract complexity. Our findings were consistent across the two treatment schema. First, our results support the hypothesis that nonprofit are used more frequently with more complex contracts. It is likely that the institutional constraints (such as the non-distribution constraint) embedded in the nonprofit organizational form mitigate some of the monitoring costs of contracting as they become more complex. As discussed previously, the nonprofit organization form is also a credible signal of goal alignment, mitigating some adverse selection problems. A potential manager or entrepreneur could have entered the market as a for-profit firm. Because nonprofits are constrained to a particular objective (and submit to higher levels of public scrutiny), they may offer a credible signal to the contracting agency as to their common objectives.

Second, we observe an increase in the use of nonprofits when relational asset specificity is higher. This is particularly interesting because it diverges from the use of cost-plus contracts. It is plausible that the nondistribution constraint (i. e. no residual claimant) may mitigate moral hazard. This is a particular concern for contracts that are both complex and relationally specific. Our results demonstrate that nonprofits are used more often in this circumstance. This finding suggests that the nonprofit organizational form may accrue some additional benefits beyond those of the cost-plus contract. It is possible that the non-distribution constraint mitigates the incentive to gold-plate contracts with additional expenditures (or lower non-contractible quality) because those marginal revenues cannot be consumed as cash. Thus the nonprofit organizational form offers potentially valuable protections when contracts are particularly non-contractible.

These findings, however, beg the question. If nonprofits are effective in mitigating transaction cost, why do we observe so few of them in the data? We suggest three possible explanations for the low prevalence of nonprofits. First, nonprofit firms may be more prevalent in secondary sub-awards. Recall that our data only included prime awards. Many of these are block grants to states. Nonprofits are often sub-contracted by state institutions for service provision, rather than through federal agencies directly. ${ }^{11}$

Alternatively, it is also possible that there exists idiosyncratic process in the federal contracting process that makes it particularly difficult to contract with nonprofits. This contingency is difficult to detect in the federal contracting dataset. However, we do note that there is wide variation across agencies in their propensity to contract with nonprofits, even after controlling for the complexity of the contract. One fruitful avenue of future research would be a deeper qualitative analysis of the various contracting idiosyncrasies of the various agencies that may prohibit working with the nonprofit sector.

A final, and interesting possibility, is that altruistic entrepreneurs are scarce and the capital constraints embedded in the nonprofit organizational form limit the scale of nonprofit enterprises (Glaeser and Shleifer 2001). It is possible that there are simply not enough nonprofits to meet the demand of federal agencies. The observation that nonprofit contracts were only subject to half as many competing bids - relative to for-profits - supports this conjecture. As they say, further investigation on each of these points is warranted. We believe that all are plausible, but we leave their exploration to future research.

\section{Appendix}

\section{A NAICS Catagoriation based on Brown \& Potoski (2005)}

\begin{tabular}{llllll}
\hline NAICS & Description & Frequency & $\begin{array}{l}\text { Ease of } \\
\text { measurement }\end{array}$ & Complex & Asset Specific \\
\hline 221210 & Gas Utility Operation and Management & 556 & No & Yes & Yes \\
221310 & Water treatment and distribution & 494 & Yes & No & Yes \\
221320 & Sewage Treatment Facilities & 166 & Yes & No & Yes \\
237110 & Water and Sewer Line and Related Structures & 683 & Yes & No & Yes
\end{tabular}


237130 Electricity utility operation and management 12

237310

238210 Traffic signal installation and maintenance

485111 Operation/Maintenance of Bus Systems

485113 Bus transit systems (except mixed mode)

488119 Airports, civil, operation and maintenance

488410 Motor Vehicle Towing \& Storage

488490 Street/Parking Lot cleaning \& snow removal

518210 Data processing services

519120 Operation of Libraries

522320 Financial Transactions Processing

532112 Fleet Management and Maintenance

541110 Legal services

541214 Payroll Services

541350 Inspection/code Enforcement

541370 Title records/plat map maintenance

541620 Environmental inspection services

541820 Public Relations Agencies

561440 Collection and Delinquent Processing

561591 Convention and visitors bureaus

561710 Insect/rodent control

561730 Parks and Landscaping Maintenance

561790 Building and Grounds Maintenance

561990 Parking Meter maintenance and collection

562111 Commercial Solid Waste Collection

562211 Solid Waste Treatment and Disposal

562212 Residential nonhazardous solid waste (e. g. trash)

621910 Ambulance and Emergency Vehicle Maintenance

622110 Operation/management of Hospitals

622210 Drug and Alcholol Treatment

623110 Programs for Elderly

623220 Mental Health Programs and Facilities

624110 Child welfare services

624221 Homeless shelters

624410 Day Care Services

712110 Museums

812220 Cemeteries and Crematories

812910 Animal Control (except Veterinary) Services

921130 Tax Assessing

922140 Prisons/jails

922160 Fire Provention/Suppression

923120 Public health program administration facilities

926110 Arts and cultural program administration, government

926130 Police/fire communications

926140 Animal Control

Total
541612 Personnel management consulting services

561410 Secretarial services

561612 Building Secturity

812930 Operation of parking garages or lots

924120 Operation and maintenance of recreation

Notes: Catagorizations based on Brown \& Potoski (2005) Table 5, pp. 340-341.

The original paper uses the term "Easy Measurement" to imply contractibility . We replace this term with Complex, whereby "Complex" implies low levels of measurability, or "Easy Measure" $=0$. We retain the word Asset Speficic, with it's original meaning.
Yes Yes

No No

No $\quad$ No

No Yes

No No

Yes Yes

No No

No No

No Yes

No Yes

No No

No No

Yes Yes

No No

Yes No

No Yes

Yes No

No No

Yes No

Yes No

No No

Yes Yes

No No

No No

No No

No No

No No

No No

No Yes

No No

Yes Yes

Yes Yes

Yes Yes

Yes Yes

Yes Yes

Yes Yes

Yes Yes

Yes Yes

Yes Yes

No No

Yes No

No No

Yes No

Yes Yes

Yes Yes

Yes Yes

No No

Yes No

No Yes

Yes No

\section{B NAICS Categorization based on Levin \& Tadelis (2010)}




\begin{tabular}{|c|c|c|c|c|}
\hline NAICS & Description & Frequency & Complex & Asset Specific \\
\hline 115310 & Fire Prevention & 4,720 & Yes & Yes \\
\hline 221310 & Water treatment and distribution & 494 & No & Yes \\
\hline 221320 & Sewage collection and water treatment & 166 & Yes & Yes \\
\hline 237310 & Street repair & 825 & No & No \\
\hline 488410 & Vehicle Towing \& Storage & 27 & No & No \\
\hline 519120 & Operation of Libraries & 61 & Yes & Yes \\
\hline 541110 & Legal Services & 2,275 & Yes & Yes \\
\hline 541350 & Commerical Solid Waste Collection & 185 & Yes & Yes \\
\hline 561440 & Delinquint tax collection services & 2 & No & No \\
\hline 561612 & Crime Prevention/Patro & 1,801 & Yes & Yes \\
\hline 561621 & Building Security & 1,398 & No & No \\
\hline 561710 & Insect/Rodent Control & 164 & Yes & No \\
\hline 561730 & Tree Trimming/planting & 79 & No & No \\
\hline 561730 & Building landscape care and maintenance services & 847 & No & No \\
\hline 561790 & Street/Parking Lot Cleaning & 237 & No & No \\
\hline 561990 & Utility Meter Reading & 439 & No & No \\
\hline 562111 & Commerical Solid Waste Collection & 547 & No & No \\
\hline 562212 & Residential Solid Waste Collection & 75 & No & No \\
\hline 562213 & Solid Waste Disposal & 59 & No & Yes \\
\hline 562998 & Sanitary Inspection & 97 & Yes & Yes \\
\hline 621420 & Drug and Alcholol Treatment & 392 & Yes & Yes \\
\hline 621493 & Emergency Medical Service & 31 & Yes & Yes \\
\hline 624120 & Programs for the elderly & 280 & Yes & Yes \\
\hline 624410 & Operation of Daycare Facilities & 7 & Yes & Yes \\
\hline 712110 & Operation of Museums & 4 & Yes & Yes \\
\hline 713940 & Operaton/Maintenance of Recreational Facilities & 26 & Yes & Yes \\
\hline 812910 & Animal Control & 29 & Yes & Yes \\
\hline \multirow[t]{2}{*}{ A } & Operation of Parking Lots and Garages & 209 & No & No \\
\hline & Total & 15,476 & & \\
\hline
\end{tabular}

Notes: Catagorizations based on Levin and Tadelis (2010) Table 2, pp. 522.

The original paper uses the term "Measure" to imply difficulty in measurement. We replace this term with "Complex", whereby Complex $=1$ if Measure $\geq 0$, zero otherwise. Further, the original paper uses the term "Holdup", we replace this term with "Asset Specific", where Asset Specific $=1$ if Holdup $\geq 1$, zero otherwise.

The original paper uses continuous variables for "Measure" and "Holdup". For comparability, we transform these variables into binomials using a criteria defined in the original Levin \& Tadelis (2010) paper. The criteria are detailed in the notes for Table

IV on p. 525. Please see the original paper for more detail.

\section{Full Regression Results for Cost Plus Dependent Variable}

$\begin{array}{lll}\text { Logistic regression } & \text { Number of obs } & =35,243 \\ & \text { LR chi2(62) } & 22,492.45 \\ & \text { Prob }>\text { chi2 } & 0 \\ \text { Log } & \text { Pseudo R2 } & 0.7074\end{array}$

likelihood $=-4652.4689$

CP

1.complex

1.specific

1.BP

state

AS: AMERICAN

SAMOA

AZ: ARIZONA

CA: CALIFORNIA

CO: COLORADO

CT: CONNECTICUT

DC: DISTRICT OF

COLUMBIA
Coef. Std Err.

1.833587

$-1.529261$

$-0.1870564$

0

0.0562482

2.782663

3.840714

3.418973

1.701006

\section{Std. Err.}

0.1086002

0.1105898

0.0608054

z

16.88

$-13.83$

$-3.08$

(empty)

$0.6618364 \quad 0.08$

$0.4763761 \quad 5.84$

0.5152999

0.5444957

0.4892527

7.45

6.28

3.48
P > z

0

0

0.002

[95 \% Conf. Interval]

$1.620735 \quad 2.046439$

$\begin{array}{ll}-1.746013 & -1.312509\end{array}$

$-0.3062328 \quad-0.06788$ 


\begin{tabular}{|c|c|c|c|c|c|c|}
\hline DE: DELAWARE & 3.114425 & 0.9049821 & 3.44 & 0.001 & 1.340693 & 4.888157 \\
\hline FL: FLORIDA & 2.956481 & 0.4896998 & 6.04 & 0 & 1.996687 & 3.916275 \\
\hline GA: GEORGIA & 2.628643 & 0.4917577 & 5.35 & 0 & 1.664816 & 3.592471 \\
\hline GU: GUAM & 5.265265 & 1.042918 & 5.05 & 0 & 3.221183 & 7.309346 \\
\hline HI: HAWAII & 4.163333 & 0.7731449 & 5.38 & 0 & 2.647997 & 5.678669 \\
\hline IA: IOWA & 2.710617 & 0.7338734 & 3.69 & 0 & 1.272251 & 4.148982 \\
\hline ID: IDAHO & 1.3788 & 0.543412 & 2.54 & 0.011 & 0.313732 & 2.443868 \\
\hline IL: ILLINOIS & 4.446254 & 0.4759548 & 9.34 & 0 & 3.5134 & 5.379108 \\
\hline IN: INDIANA & 2.991486 & 0.5047879 & 5.93 & 0 & 2.00212 & 3.980852 \\
\hline KS: KANSAS & 2.104535 & 0.6962033 & 3.02 & 0.003 & 0.7400014 & 3.469068 \\
\hline KY: KENTUCKY & 3.027073 & 0.5079721 & 5.96 & 0 & 2.031465 & 4.02268 \\
\hline LA: LOUISIANA & 2.646888 & 0.6179491 & 4.28 & 0 & 1.43573 & 3.858046 \\
\hline MA: MASSACHUSETTS & 3.97564 & 0.4970878 & 8.00 & 0 & 3.001366 & 4.949914 \\
\hline MD: MARYLAND & 2.379983 & 0.4946249 & 4.81 & 0 & 1.410536 & 3.349429 \\
\hline ME: MAINE & 4.708887 & 0.6430212 & 7.32 & 0 & 3.448589 & 5.969186 \\
\hline MI: MICHIGAN & 5.440404 & 0.4952007 & 10.99 & 0 & 4.469828 & 6.41098 \\
\hline MN: MINNESOTA & 2.425598 & 0.5156523 & 4.70 & 0 & 1.414938 & 3.436258 \\
\hline MO: MISSOURI & 1.661399 & 0.5713432 & 2.91 & 0.004 & 0.5415872 & 2.781211 \\
\hline MP: NORTHERN & 0 & (empty) & & & & \\
\hline \multicolumn{7}{|l|}{ MARIANA ISLANDS } \\
\hline MS: MISSISSIPPI & 4.207447 & 0.5514955 & 7.63 & 0 & 3.126536 & 5.288359 \\
\hline MT: MONTANA & 3.420495 & 0.5107249 & 6.70 & 0 & 2.419493 & 4.421498 \\
\hline NC: NORTH & 3.553362 & 0.5236185 & 6.79 & 0 & 2.527089 & 4.579635 \\
\hline \multicolumn{7}{|l|}{ CAROLINA } \\
\hline ND: NORTH DAKOTA & 0.1331825 & 0.6976875 & 0.19 & 0.849 & -1.23426 & 1.500625 \\
\hline NE: NEBRASKA & 4.654871 & 0.5578041 & 8.34 & 0 & 3.561595 & 5.748147 \\
\hline NH: NEW HAMPSHIRE & 4.824934 & 0.5843025 & 8.26 & 0 & 3.679722 & 5.970146 \\
\hline NJ: NEW JERSEY & -0.5385385 & 0.9127414 & -0.59 & 0.555 & -2.327479 & 1.250402 \\
\hline NM: NEW MEXICO & 1.46463 & 0.5174967 & 2.83 & 0.005 & 0.4503551 & 2.478905 \\
\hline NV: NEVADA & 3.61693 & 0.5230647 & 6.91 & 0 & 2.591742 & 4.642118 \\
\hline NY: NEW YORK & 4.289626 & 0.4787745 & 8.96 & 0 & 3.351245 & 5.228007 \\
\hline $\mathrm{OH}: \mathrm{OHIO}$ & 4.8086 & 0.5046555 & 9.53 & 0 & 3.819493 & 5.797706 \\
\hline OK: OKLAHOMA & 1.527265 & 0.4948662 & 3.09 & 0.002 & 0.5573447 & 2.497185 \\
\hline OR: OREGON & 3.237706 & 0.4777378 & 6.78 & 0 & 2.301357 & 4.174055 \\
\hline PA: PENNSYLVANIA & 3.397217 & 0.4798619 & 7.08 & 0 & 2.456705 & 4.337729 \\
\hline PR: PUERTO RICO & 3.211731 & 0.6843805 & 4.69 & 0 & 1.87037 & 4.553092 \\
\hline RI: RHODE ISLAND & 3.065145 & 0.9286885 & 3.30 & 0.001 & 1.244949 & 4.885341 \\
\hline SC: SOUTH CAROLINA & -0.7779598 & 0.7762109 & -1.00 & 0.316 & -2.299305 & 0.7433855 \\
\hline SD: SOUTH DAKOTA & 4.060294 & 0.4914795 & 8.26 & 0 & 3.097012 & 5.023576 \\
\hline TN: TENNESSEE & 3.712655 & 0.5091525 & 7.29 & 0 & 2.714735 & 4.710576 \\
\hline TX: TEXAS & 4.013843 & 0.4709576 & 8.52 & 0 & 3.090784 & 4.936903 \\
\hline UT: UTAH & 2.161051 & 0.8055375 & 2.68 & 0.007 & 0.5822263 & 3.739875 \\
\hline VA: VIRGINIA & 3.448576 & 0.4808361 & 7.17 & 0 & 2.506154 & 4.390997 \\
\hline VI: VIRGIN ISLANDS & 3.882387 & 1.145659 & 3.39 & 0.001 & 1.636938 & 6.127837 \\
\hline \multicolumn{7}{|l|}{ OF THE U.S. } \\
\hline VT: VERMONT & 4.536123 & 0.8192073 & 5.54 & 0 & 2.930506 & 6.14174 \\
\hline WA: WASHINGTON & 1.0342 & 0.5650424 & 1.83 & 0.067 & -0.0732629 & 2.141663 \\
\hline WI: WISCONSIN & 6.986821 & 0.5066395 & 13.79 & 0 & 5.993826 & 7.979816 \\
\hline WV: WEST VIRGINIA & 0.3898719 & 0.6914875 & 0.56 & 0.573 & -0.9654187 & 1.745163 \\
\hline WY: WYOMING & -0.5237732 & 0.8581224 & -0.61 & 0.542 & -2.205662 & 1.158116 \\
\hline \multicolumn{7}{|l|}{ agency } \\
\hline $\begin{array}{l}\text { 1500: JUSTICE, } \\
\text { DEPARTMENT OF }\end{array}$ & 4.913362 & 0.1417203 & 34.67 & 0 & 4.635595 & 5.191128 \\
\hline 3600: VETERANS & -2.728936 & 0.5729936 & -4.76 & 0 & -3.851983 & -1.605889 \\
\hline \multicolumn{7}{|l|}{ AFFAIRS, } \\
\hline \multicolumn{7}{|l|}{ DEPARTMENT OF } \\
\hline 4700: GENERAL & -0.0479361 & 0.2895837 & -0.17 & 0.869 & -0.6155096 & 0.5196375 \\
\hline \multicolumn{7}{|l|}{ SERVICES } \\
\hline \multicolumn{7}{|l|}{ ADMINISTRATION } \\
\hline 7500: HEALTH AND & 4.593395 & 0.1391418 & 33.01 & 0 & 4.320682 & 4.866108 \\
\hline \multirow{2}{*}{\multicolumn{7}{|c|}{$\begin{array}{l}\text { HUMAN SERVICES, } \\
\text { DEPARTMENT OF }\end{array}$}} \\
\hline & & & & & & \\
\hline log_bids & 0.8533655 & 0.0617883 & 13.81 & 0 & 0.7322627 & 0.9744684 \\
\hline log_duration_years & 3.89159 & 0.0786222 & 49.50 & 0 & 3.737493 & 4.045686 \\
\hline
\end{tabular}




\begin{tabular}{lllllll} 
log_contractvalue & -0.2187655 & 0.0200203 & -10.93 & 0 & -0.2580047 & -0.1795264 \\
log_contractorrevenue & -0.1368296 & 0.0043368 & -31.55 & 0 & -0.1453296 & -0.1283296 \\
_cons & -10.38444 & 0.5013778 & -20.71 & 0 & -11.36712 & -9.401759 \\
\hline
\end{tabular}

\section{Full Regression Results for Nonprofit Dependent Variable}

\begin{tabular}{|c|c|c|c|c|c|c|}
\hline Logistic regression & $\begin{array}{l}\text { Number of } \\
\text { obs } \\
\text { LR chi2(59) } \\
\text { Prob > chi2 } \\
\text { Pseudo R2 } \\
\text { Coef. }\end{array}$ & $\begin{array}{l}=35,184 \\
9893.38 \\
0 \\
0.4299 \\
\text { Std. Err. z }\end{array}$ & $\mathbf{z}$ & $\mathbf{P}>\mathbf{z}$ & [95\% Conf. & val] \\
\hline 1.complex & 2.11236 & 0.094072 & 22.45 & 0 & 1.927982 & 2.296738 \\
\hline 1.specific & 0.9619969 & 0.1048007 & 9.18 & 0 & 0.7565913 & 1.167402 \\
\hline 1.BP & 0.7776455 & 0.0712893 & 10.91 & 0 & 0.6379212 & 0.9173699 \\
\hline \multicolumn{7}{|l|}{ state } \\
\hline AS: AMERICAN SAMOA & 0 & (empty) & & & & \\
\hline AZ: ARIZONA & 1.036381 & 0.3889036 & 2.66 & 0.008 & 0.2741438 & 1.798618 \\
\hline CA: CALIFORNIA & 1.035441 & 0.3571377 & 2.90 & 0.004 & 0.3354636 & 1.735418 \\
\hline CO: COLORADO & 1.076877 & 0.4040504 & 2.67 & 0.008 & 0.2849529 & 1.868801 \\
\hline CT: CONNECTICUT & 0.0947018 & 0.4972425 & 0.19 & 0.849 & -0.8798755 & 1.069279 \\
\hline DC: DISTRICT OF & 1.214917 & 0.3806904 & 3.19 & 0.001 & 0.4687775 & 1.961056 \\
\hline \multicolumn{7}{|l|}{ COLUMBIA } \\
\hline DE: DELAWARE & 0 & (empty) & & & & \\
\hline FL: FLORIDA & 0.4028498 & 0.3664478 & 1.10 & 0.272 & -0.3153748 & 1.121074 \\
\hline GA: GEORGIA & 0.8999806 & 0.4209622 & 2.14 & 0.033 & 0.0749098 & 1.725051 \\
\hline GU: GUAM & 0 & (empty) & & & & \\
\hline HI: HAWAII & 1.639421 & 0.5476714 & 2.99 & 0.003 & 0.5660042 & 2.712837 \\
\hline IA: IOWA & 2.608792 & 0.4316448 & 6.04 & 0 & 1.762784 & 3.454801 \\
\hline ID: IDAHO & -0.2036415 & 0.415993 & -0.49 & 0.624 & -1.018973 & 0.6116898 \\
\hline IL: ILLINOIS & 1.729999 & 0.3576265 & 4.84 & 0 & 1.029064 & 2.430934 \\
\hline IN: INDIANA & -0.7168797 & 0.4120502 & -1.74 & 0.082 & -1.524483 & 0.0907239 \\
\hline KS: KANSAS & 0.2124366 & 0.5304412 & 0.40 & 0.689 & -0.8272091 & 1.252082 \\
\hline KY: KENTUCKY & 1.048517 & 0.3835558 & 2.73 & 0.006 & 0.2967609 & 1.800272 \\
\hline LA: LOUISIANA & 0.9869307 & 0.4464305 & 2.21 & 0.027 & 0.111943 & 1.861918 \\
\hline MA: MASSACHUSETTS & 0.2941122 & 0.4105695 & 0.72 & 0.474 & -0.5105893 & 1.098814 \\
\hline MD: MARYLAND & 1.302451 & 0.3887846 & 3.35 & 0.001 & 0.5404469 & 2.064454 \\
\hline ME: MAINE & 1.95879 & 0.5567817 & 3.52 & 0 & 0.8675181 & 3.050062 \\
\hline MI: MICHIGAN & 1.297068 & 0.3893939 & 3.33 & 0.001 & 0.5338703 & 2.060266 \\
\hline MN: MINNESOTA & 2.231415 & 0.3626266 & 6.15 & 0 & 1.52068 & 2.94215 \\
\hline MO: MISSOURI & 2.602906 & 0.3688589 & 7.06 & 0 & 1.879956 & 3.325856 \\
\hline MP: NORTHERN & 0 & (empty) & & & & \\
\hline \multicolumn{7}{|l|}{ MARIANA ISLANDS } \\
\hline MS: MISSISSIPPI & -0.8511624 & 0.799746 & -1.06 & 0.287 & -2.418636 & 0.716311 \\
\hline MT: MONTANA & 1.38501 & 0.4272019 & 3.24 & 0.001 & 0.5477096 & 2.22231 \\
\hline NC: NORTH CAROLINA & 0.6707337 & 0.443587 & 1.51 & 0.131 & -0.1986808 & 1.540148 \\
\hline ND: NORTH DAKOTA & 2.776283 & 0.4266712 & 6.51 & 0 & 1.940023 & 3.612543 \\
\hline NE: NEBRASKA & 1.336363 & 0.4658002 & 2.87 & 0.004 & 0.4234112 & 2.249314 \\
\hline NH: NEW HAMPSHIRE & -0.7372171 & 0.8134346 & -0.91 & 0.365 & -2.33152 & 0.8570855 \\
\hline NJ: NEW JERSEY & 2.065029 & 0.3550049 & 5.82 & 0 & 1.369232 & 2.760826 \\
\hline NM: NEW MEXICO & 1.405203 & 0.438406 & 3.21 & 0.001 & 0.545943 & 2.264463 \\
\hline NV: NEVADA & 0.897032 & 0.5117248 & 1.75 & 0.08 & -0.1059302 & 1.899994 \\
\hline NY: NEW YORK & 1.060008 & 0.370957 & 2.86 & 0.004 & 0.3329454 & 1.78707 \\
\hline OH: OHIO & 1.639098 & 0.3680579 & 4.45 & 0 & 0.9177177 & 2.360478 \\
\hline OK: OKLAHOMA & -0.5509361 & 0.5732574 & -0.96 & 0.337 & -1.6745 & 0.5726278 \\
\hline OR: OREGON & -1.174985 & 0.417095 & -2.82 & 0.005 & -1.992476 & -0.3574936 \\
\hline PA: PENNSYLVANIA & 1.921221 & 0.3604629 & 5.33 & 0 & 1.214727 & 2.627716 \\
\hline PR: PUERTO RICO & 0.8288848 & 0.5151726 & 1.61 & 0.108 & -0.180835 & 1.838605 \\
\hline RI: RHODE ISLAND & 1.647223 & 0.7184524 & 2.29 & 0.022 & 0.239082 & 3.055364 \\
\hline
\end{tabular}




\begin{tabular}{|c|c|c|c|c|c|c|}
\hline SC: SOUTH CAROLINA & -0.7980878 & 0.5479269 & -1.46 & 0.145 & -1.872005 & 0.2758291 \\
\hline SD: SOUTH DAKOTA & 1.846042 & 0.3847244 & 4.80 & 0 & 1.091996 & 2.600088 \\
\hline TN: TENNESSEE & 0.2989907 & 0.4812112 & 0.62 & 0.534 & -0.644166 & 1.242147 \\
\hline TX: TEXAS & -0.3950686 & 0.3705422 & -1.07 & 0.286 & -1.121318 & 0.3311808 \\
\hline UT: UTAH & 1.599635 & 0.4673269 & 3.42 & 0.001 & 0.6836916 & 2.515579 \\
\hline VA: VIRGINIA & 0.5945241 & 0.4018357 & 1.48 & 0.139 & -0.1930595 & 1.382108 \\
\hline $\begin{array}{l}\text { VI: VIRGIN ISLANDS OF } \\
\text { THE U.S. }\end{array}$ & 0 & (empty) & & & & \\
\hline VT: VERMONT & 2.978125 & 0.4926585 & 6.05 & 0 & 2.012532 & 3.943718 \\
\hline WA: WASHINGTON & 0.0897415 & 0.4559965 & 0.20 & 0.844 & -0.8039952 & 0.9834781 \\
\hline WI: WISCONSIN & 0.9168262 & 0.3986777 & 2.30 & 0.021 & 0.1354322 & 1.69822 \\
\hline WV: WEST VIRGINIA & 1.068811 & 0.3623922 & 2.95 & 0.003 & 0.3585358 & 1.779087 \\
\hline WY: WYOMING & 1.433031 & 0.5590565 & 2.56 & 0.01 & 0.3373 & 2.528761 \\
\hline agency & & & & & & \\
\hline $\begin{array}{l}\text { 1500: JUSTICE, } \\
\text { DEPARTMENT OF }\end{array}$ & 2.088716 & 0.1323388 & 15.78 & 0 & 1.829337 & 2.348095 \\
\hline $\begin{array}{l}\text { 3600: VETERANS } \\
\text { AFFAIRS, DEPARTMENT } \\
\text { OF }\end{array}$ & 1.922656 & 0.1387958 & 13.85 & 0 & 1.650621 & 2.19469 \\
\hline $\begin{array}{l}\text { 4700: GENERAL } \\
\text { SERVICES } \\
\text { ADMINISTRATION }\end{array}$ & 2.37473 & 0.1879444 & 12.64 & 0 & 2.006365 & 2.743094 \\
\hline $\begin{array}{l}\text { 7500: HEALTH AND } \\
\text { HUMAN SERVICES, } \\
\text { DEPARTMENT OF }\end{array}$ & 0.9455045 & 0.182747 & 5.17 & 0 & 0.587327 & 1.303682 \\
\hline log_bids & -1.128033 & 0.0774573 & -14.56 & 0 & -1.279846 & -0.9762194 \\
\hline log_duration_years & -1.430087 & 0.0835829 & -17.11 & 0 & -1.593906 & -1.266267 \\
\hline log_contractvalue & 0.1023375 & 0.0172709 & 5.93 & 0 & 0.0684872 & 0.1361877 \\
\hline log_contractorrevenue & 0.0425792 & 0.0042024 & 10.13 & 0 & 0.0343426 & 0.0508159 \\
\hline _cons & -7.468762 & 0.3753355 & -19.90 & 0 & -8.204406 & -6.733118 \\
\hline
\end{tabular}

\section{Notes}

1 Nonprofit firms may consume residual profits as non-cash perquisites (i. e. plush offices, short work weeks, etc.), which would reduce the effectiveness of the nondistribution constraint along this margin. See Castaneda, Garen, and Thornton (2008) for a review of this literature. 2 Except under special circumstances, Federal Acquisition Regulations (FAR) typically mandate that government agencies use fixed (relative to cost-plus) price contracts (Carril and Duggan 2018).

3 The cost-plus contract, as identified in this paper, includes all of the following cost-plus style pricing schemes: cost-plus award fee, cost no fee; cost sharing; cost-plus fixed fee; cost-plus incentive; time and materials, labor hours. The fixed price contracts, as identified in this paper includes all of the following fixed price style pricing schemes: fixed price redetermination, fixe price level effort, firm fixed price, fixed price with economic price adjustment, fixed price inventive, fixed price award fee.

4 Recall that our analysis is restricted to the NAICS contract codes included in those two papers, reducing the sample to 35,588 unique contracts. The NAICS stands for the North American Industry Classification System (NAICS), which was developed by the Office and Management and Budget as a method for classifying business establishments. Further information is available at http://www.census.gov/eos/www/naics/.

5 The services in the survey were derived from those listed in the International City/ County Managers Association (ICMA) survey. See page 335 of the original article for a complete description of the scale and the survey instrument.

6 A complete list of contracts extracted from Brown and Potoski (2005) available in Appendix A.

7 A complete list of contracts extracted in Levin and Tadelis (2010) available in Appendix B.

8 For Brown and Potoski (2005), we use Table 4, pp. 336-337, which organizes survey responses into binomial form. For Levin and Tadelis (2010), we apply the notes from Table 4 on p. 525 to transform the survey responses.

9 The number of observations within the conflicting NAICS codes is small, just 142 . We experiment with a variety of different strategies for handing the conflicting data. Because each treatment BP and LT are estimated separately, we decide to leave in the conflicting observations. However, our results were not materially influenced if those observations are removed.

10 These additional results are available from the authors, upon request.

11 For more detail on how nonprofit award data is structured, see (Lecy and Thornton 2016).

\section{References}

Alchian, A. A., and H. Demsetz. 1972. “Production Costs, Information Costs, and Economic Organization.” American Economic Review 62 (5): 777-95. https://doi.org/10.1109/EMR.1975.4306431.

Bajari, P., S. Houghton, and S. Tadelis. 2014. “Bidding for Incomplete Contracts: an Empirical Analysis of Adaptation Costs." American Economic Review 104 (4): 1288-319. https://doi.org/10.1257/aer.104.4.1288. 
Bajari, P., and S. Tadelis. 2001. "Incentives Versus Transaction Costs: A Theory of Procurement Contracts." The RAND Journal of Economics Journal of Economics 32 (3): 387-407. https://doi.org/10.2307/2696361.

Bennett, ], and E. lossa 2007. “Contracting Out Public Service Provision to Non-for-profit Firms.” Retrieved from http://www.brunel.ac.uk/about/acad/sssl/ssslresearch/efwps\#\#2004.

Bennett, John, and E. lossa. 2009. “Contracting Out Public Service Provision to Not-for-profit Firms." Oxford Economic Papers 62 (4): 784-802. https://doi.org/10.1093/oep/gppo40.

Bennett, John, E. lossa, and G. Legrenzi. 2003. “The Role of Commercial Non- Profit Organizations in the Provision of Public Services." Oxford Review of Economic Policy 19 (2): 335-47. https://doi.org/10.1093/oxrep/19.2.335.

Besley, T., and M. Ghatak. 2001. “Covernment Versus Private Ownership of Public Coods.” The Quarterly Journal of Economics 116 (4): $1343-72$. https://doi.org/10.1162/003355301753265598.

Boerner, C. S., and J. Macher. 2008. “Transaction Cost Economics: An Assessment of Empirical Research in the Social Sciences." Business and Politics 10 (1): 1-63. https://doi.org/10.2202/1469-3569.1210.

Brown, L. K., and E. Troutt. 2004. "Funding Relations between Nonprofits and Government: A Positive Example." Nonprofit and Voluntary Sector Quarterly 33 (1): 5-27. https://doi.org/10.1177/0899764003260601.

Brown, T. L., M. Potoski, and D. Van Slyke. 2016. “Managing Complex Contracts: A Theoretical Approach." Journal of Public Administration Research and Theory 26 (2): 294-308. https://doi.org/10.1093/jopart/muvo04.

Brown, T. L., M. Potoski, and D. M. Van Slyke. 2006. "Managing Public Service Contracts: Aligning Values, Institutions, and Markets." Managing Public Service Contracts 66: 323-31. https://doi.org/10.1111/j.1540-6210.2006.00590.x.

Brown, T. L., M. Potoski, and D. M. Van Slyke. 2010. “Contracting for Complex Products." Journal of Public Administration Research and Theory 20 (SUPPL. 1): 41-58. https://doi.org/10.1093/jopart/mupo34.

Brown, T. L., M. Potoski, and D. M. Van Slyke. 2015. “The Impact of Transaction Costs on the Use of Mixed Service Delivery by Local Covernments." Journal of Strategic Contracting and Negotiation 1 (4): 239-67. https://doi.org/10.1177/2055563616631563.

Brown, T. L. L., and M. Potoski. 2005. “Transaction Costs and Contracting: The Practitioner Perspective." Public Performance $\&$ Management Review 28 (3): 326-51. https://doi.org/10.1080/15309576.2005.11051842.

Brown, W. 2005. “Organizational Performance in Nonprofit Organizations.” Nonprofit Management and Leadership 15 (3): 317-39. https://doi.org/10.1002/nml.71.

Bryce, H. 2012. “Players in the Public Policy Process: Nonprofits as Social Capital and Agents.” Retrieved from https://books.google.com/books?hl=en\&id=Rd7IAAAAQBA]\&oi=fnd\&pg=PP1\&dq=Players+in+the+public+policy+process:+Nonprofits+as+social+capit TbhFO8dBobknc97AgZaQI.

Carril, R., and M. Duggan 2018. “The Impact of Industry Consolidation on Covernment Procurement: Evidence from Department of Defense Contracting." National Bureau of Economic Research, (25160). Retrieved from http://www.nber.org/papers/w25160.

Castaneda, M. A. M. A., J. Garen, and J. Thornton. 2008. "Competition, Contractibility, and the Market for Donors to Nonprofits." Journal of Law, Economics, and Organization 24 (1): 215-46. https://doi.org/10.1093/jleo/ewmo36.

Crocker, K. J., and K. J. Reynolds. 1993. "The Efficiency of Incomplete Contracts: An Empirical Analysis of Air Force Engine Procurement." The RAND Journal of Economics 24 (1): 126. https://doi.org/10.2307/2555956.

Fama, E. F., and M. C. Jensen. 1983. "Separation of Ownership and Control." The Journal of Law and Economics 26 (2): 301. https://doi.org/10.1086/467037.

Feiock, R. C., and H. S. Jang. 2009. “Nonprofits as Local Covernment Service Contractors.” Public Administration Review. https://doi.org/10.1111/j.1540-6210.2009.02016.x.

Fernandez, S. 2009. “Understanding Contracting Performance: An Empirical Analysis.” Administration \& Society 41. https://doi.org/10.1177/0095399708330257.

Ferris, J. M., and E. Graddy. 1991. “Production Costs, Transaction Costs, and Local Covernment Contractor Choice.” Economic Inquiry 29 (3): 541-54. https://doi.org/10.1111/j.1465-7295.1991.tboo845.x.

Claeser, E. L., and A. Shleifer. 2001. “Not-for-profit Entrepreneurs." Journal of Public Economics 81 (1): 99-115. https://doi.org/10.1016/So0472727(00)00130-4.

Hansmann, H.B. 1980. “The Role of Nonprofit Enterprise." The Yale Law Journal 89 (5): 835-901. https://doi.org/10.1021/ja804069n.

Hart, O., and J. Moore. 2008. “Contracts as Reference Points." Quarterly Journal of Economics 123 (1): 1-48. https://doi.org/10.1162/qjec.2008.123.1.1.

Hopkins, B. R. 2011. The Law of Tax-exempt Organizations, J. Wiley. Retrieved from https://books.google.com/books?hl=en\&id=NRowWFkLxf8C\&oi=fnd\&pg=PR o]IB1_KE1CzM-8bwoe6EA\#v=onepage\&q\&f=false.

Iossa, E., and D. Martimort. 2016. "Corruption in PPPs, Incentives and Contract Incompleteness." International Journal of Industrial Organization 44: 85-100. https://doi.org/10.1016/J.IJINDORG.2015.10.007.

Jensen, M. C. 2016. "Agency Costs of Free Cash Flow, Corporate Finance, and Takeovers." The American Economic Review 76 (2): $323-29$.

Jensen, M. H., and W. H. Meckling. 1976. "Theory of the Firm: Managerial Behavior, Agency Costs and Ownership Structure." Journal of Financial Economics 3 (4): 305-60. https://doi.org/http://dx.doi.org/10.1016/0304-405X(76)90026-X.

Kim, Y., and T. Brown. 2012. "The Importance of Contract Design." Public Administration Review 72 (5): 687-96. https://doi.org/10.1111/j.15406210.2012.02537.X.

Kim, Y. W., A. Roberts, and T. Brown. 2016. "Impact of Product Characteristics and Market Conditions on Contract Type: Use of Fixed-Price Versus Cost-Reimbursement Contracts in the U.S. Department of Defense." Public Performance and Management Review 39 (4): $783-813$. https://doi.org/10.1080/15309576.2015.1137765.

Lamothe, S., and M. Lamothe. 2006. "The Dynamics of Local Service Delivery Arrangements and the Role of Nonprofits." International Journal of Public Administration 29 (10-11): 769-97. https://doi.org/10.1080/01900690600770454.

Lecy, J. D., and J. Thornton. 2016. "What Big Data Can Tell Us about Government Awards to the Nonprofit Sector: Using the FAADS." Nonprofit and Voluntary Sector Quarterly 45 (5): 1052-69. https://doi.org/10.1177/0899764015620902. 
Levin, J., and S. Tadelis. 2010. “Contracting for Covernment Services : Theory and Evidence from U.S. Cities." Journal of Industrial Economics 58 (3): 507-41. https://doi.org/10.1111/j.1467-6451.2010.00430.x.

Prüfer, ]. 2011. “Competition and Mergers among Nonprofits." Journal of Competition Law and Economics 7 (1): 69-92. https://doi.org/10.1093/joclec/nhq015.

Tadelis, S, and P. Bajari. 2006. "Incentives and Award Procedures: Competitive Tendering vs. Negotiations in Procurement." In Handbook of Procurement, 121-39. Retrieved from http://ecms-ext.bond.edu.au/prod_ext/groups/public/@pub-sdagen/documents/genericwebdocument/bd3_021696.pdf.

Tadelis, Steven. 2002. “Complexity, Flexibility, and the Make-or-Buy Decision." The American Economic Review 92 (2): 433-37. https://doi.org/10.1257/000282802320191750.

Tadelis, Steven, and O. Williamson. 2012. “Transaction Cost Economics.” In Handbook of Organizational Economics, 159-90. https://doi.org/10.2139/ssrn.263511.

Valentinov, V. 2007. "Some Reflections on the Transaction Cost Theory of Nonprofit Organisation." Journal for Public and Nonprofit Services 30 (1): 52-67. https://doi.org/10.5771/0344-9777-2007-1-52.

Valentinov, V. 2014. "The Complexity-Sustainability Trade-Off in Niklas Luhmann's Social Systems Theory." Systems Research and Behavioral Science 31 (1): 14-22. https://doi.org/10.1002/sres.2146.

Valentinov, V., and L. Chatalova. 2016. “Institutional Economics and Social Dilemmas: A Systems Theory Perspective." Systems Research and Behavioral Science 33 (1): 138-49. https://doi.org/10.1002/sres.2327.

Van Slyke, D. M. 2007. “Agents or Stewards: Using Theory to Understand the Covernment-nonprofit Social Service Contracting Relationship." Journal of Public Administration Research and Theory 17 (2): 157-87. https://doi.org/10.1093/jopart/mulo12.

Williamson, O. E. 1979. "Transaction-Cost Economics: the Covernance of Contractual Relations." The Journal of Law and Economics 22 (2): $233-$ 61. https://doi.org/10.1086/466942.

Williamson, O. E. 1981. “The Economics of Organization: The Transaction Cost Approach." American Journal of Sociology 87 (3): 548-77. https://doi.org/10.1086/227496.

Witesman, E. M., and S. Fernandez. 2012. “Covernment Contracts with Private Organizations: are there Differences between Nonprofits and For-profits?" Nonprofit and Voluntary Sector Quarterly 42 (4): 689-715. https://doi.org/10.1177/0899764012442592.

Young, D. R., R. Aranson, T. Jung, and R. Aranson. 2010. "Mission-Market Tensions and Nonprofit Pricing." The American Review of Public Administration 40 (2): 153-69. https://doi.org/10.1177/0275074009335411.

Young, D. R., and ]. Casey. 2006. "Complementary, Supplementary or Adversarial? Nonprofit-government Relations." In Nonprofits and Covernment: Collaboration and Conflict, edited by E. T. Boris, and C. E. Steuerle, 37-80. Washington D.C: Urban Institute. 